\title{
Pediatrist Gözüyle Çocukluk Çağı Nekrotizan Fasiite Bakış: Bir Derleme
}

\section{Overview of Childhood Necrotizing Fasciitis Through The Pediatrician: A Review}

\author{
Mervan Bekdaş \\ Abant İzzet Baysal Üniversitesi Tip Fakültesi Çocuk Sağlı̆̆ı ve Hastalıkları AD, Bolu, Türkiye \\ Yazıșma Adresi / Correspondence: \\ Mervan Bekdaș \\ Abant İzzet Baysal Üniversitesi Tip Fakültesi Çocuk Sağlığı ve Hastalıkları AD, Bolu, Türkiye \\ T: +903742534656 E-mail: merbek14@yahoo.com \\ Geliş Tarihi / Received : 28.12.2018 Kabul Tarihi / Accepted : 22.04.2019 \\ Orcid: \\ Mervan Bekdaș https://orcid.org0000-0003-2469-9509
}

Öz

Nekrotizan fasiit, kas haricinde subkutan doku ve fasyayı tutan hızlı seyirli bir enfeksiyon hastalı̆̆ıdır. Vücudun herhangi bir yerini etkileyebilir. Atipik semptomlarla seyreden, genellikle küçük, enfekte bir lezyonla başlar ve hızlıca yayılır. Olgulara başlangıçta, tedavi gecikmelerine yol açan selülit tanısı yanlışlıkla konulabilmektedir. Erken tanı için hastalığı akla getirmek çok önemlidir. Ancak, hastalık çocukluk çağında nadiren görüldüğü için bu her zaman mümkün olamamaktadır. Ne yazık ki, doğrudan hastalığı gösteren laboratuvar bulgusu da yoktur. Son yıllarda hastalığın tedavisindeki ilerlemeye rağmen, ölüm oranı hala yüksek seyretmektedir. Hızlı progresyondan dolayı, erken ve agresif cerrahi debridman mortaliteyi azaltmak için çok önemlidir.

Başarılı bir tedavi için cerrahlar gereklidir, ancak morbidite ve mortaliteyi azaltacak olan esas etken hastalığın tanısının erkenden konulmasıdır, bunu sağlayacak olanlar da pediatristlerdir. Bu çalışmanın amacı, pediatristlerin desteğiyle bu hastaların tanısının daha erken konulması ve daha etkin tedavi edilmesine katkı sağlamaktır. ( Sakarya Tip Dergisi 2019, 9(2):190-198 )

Anahtar Fasiit; Nekrotizan; Pediatri; Çocuk

Kelimeler

Abstract

Necrotizing fasciitis is a progressive infectious disease that primarily involves the fascia and subcutaneous tissue without involvement of the muscle. It can affect any part of the body. It starts with an, often small, infected lesion with atypical symptoms, which then quickly develops into a rapid spreading. It may be initially misdiagnosed as cellulitis, leading to treatment delays. remember of the disease is very important for early diagnosis. However, this is not very probable as it is seen rarely in childhood. Unfortunately, there are also no laboratory findings showing disease directly. Despite the improvements in treatment over the past few decades, mortality rate still remains high. Due to rapid progression, early and aggressive surgical debridement are crucial to reduce mortality.

Surgeons are required for successful treatment, but the main factor that will reduce morbidity and mortality is early diagnosis of this disease, and pediatricians are the ones who will do this. The aim of this study is to contribute to earlier diagnosis and more effective treatment of these patients with support of pediatricians. ( Sakarya Med J 2019, 9(2):190-198 ).

Keywords Fasciitis; Necrotizing; Pediatrics; Child 


\section{GİRIŞ}

Nekrotizan fasiit (NF), yüzeyel cilt enfeksiyonlarının alt fasyal alanlara doğru hızlı ilerlemesi ile karakterize, hayatı tehdit eden bir yumuşak doku enfeksiyonudur. Hastalık subkutan dokuları ve fasyayı etkiler, kas tutulumu ise nadirdir. ${ }^{1}$ Etkilenen fasya sadece müsküler fasya değil, deri ile kas arasında yer alan tüm fasyal alanlardır. Cilt nekrozunun her zaman olmayıp, fasya nekrozunun değişmez bir bulgu olduğu bu hastalığın tanımını ilk kez 1952 y1lında Wilson yapmıştır. ${ }^{2}$ Çocukluk çağında nadiren saptanmaktadır. Tablo genellikle daha önceden sağlıklı olan çocuklarda minör bir travma sonrasında başlamaktadır. Sıklıkla ekstremitelerin tutulduğu bu hastalığın mortalitesi geç tanı ve tedaviye bağlı olarak artmaktadır. Tedavinin temelini geniş spektrumlu antibiyotik ve erken debridman oluşturmaktadır. ${ }^{1}$

Yerel veya uluslararası literatürde ülkemizden son 20 yıllık dönem içinde 13 tane çocukluk çağı NF ile ilgili yayın tespit edilmiştir ve bunların büyük kısmı (\%84) olgu sunumu şeklindedir.-12 Bir tanesi tüm yaş gruplarını içeren büyük bir seri olmasına rağmen, bu çalışmada çocukluk çağına ait sadece 4 olguya yer verilmiştir. ${ }^{13}$ Çocukluk çağı NF olgularına ait en büyük seri 13 vaka içeren Bingol-Kologlu ve ark serisidir (Tablo 1). ${ }^{14}$

Bu çalışmada son 20 yıllık dönem içinde ülkemizden yapılan çocukluk çağı NF yayınları eşliğinde konunun mevcut durumu gözden geçirilecektir. Geç tanı ve tedaviye bağlı olarak mortalitesi artan bu hastalık konusunda pediatristlerin de dikkatli olması gereklidir. Bu çalışmanın amacı da, pediatristlerin desteğiyle bu hastaların tanısının daha erken konulmasına ve daha etkin tedavi edilebilmelerine katkı sağlamaktır.
Tablo 1: Ülkemizden yapılan çocukluk çağı NF yayınlarındaki olguların demografik özellikleri

\begin{tabular}{|c|c|c|c|c|}
\hline Kaynak & $\begin{array}{c}\text { Yayın } \\
\text { y1li }\end{array}$ & $\begin{array}{l}\text { Olgu } \\
\text { sayis1 }\end{array}$ & Yaş & Cins \\
\hline Şentürk S ${ }^{3}$ & 2002 & 1 & 3 yaş & $\mathrm{K} 1 \mathrm{z}$ \\
\hline Sütçü $\mathrm{M}^{4}$ & 2016 & 2 & $6 / 9$ ay & Kız/Erkek \\
\hline Paksu Ş 5 & 2006 & 1 & 11 yaş & Erkek \\
\hline Gundeslioglu $\mathrm{AO}^{6}$ & 2014 & 2 & $2.5 / 4$ yaş & $\mathrm{K} 1 \mathrm{z}$ \\
\hline Akın $Y^{7}$ & 2013 & 1 & 15 ay & $\mathrm{K} 1 \mathrm{z}$ \\
\hline Kuzdan $C^{8}$ & 2011 & 1 & 12 yaş & $\mathrm{K} 1 \mathrm{z}$ \\
\hline Saz EU ${ }^{9}$ & 2010 & 1 & 3 yaş & Erkek \\
\hline Kurekci $\mathrm{AE}^{10}$ & 2005 & 1 & 4 yaş & $\mathrm{K} 1 \mathrm{z}$ \\
\hline Delibaş A $^{11}$ & 2005 & 1 & 14 ay & Erkek \\
\hline Ozkan $\mathrm{H}^{12}$ & 1997 & 1 & 10 gün & Erkek \\
\hline Tanir $G^{13}$ & 2006 & 4 & Bilinmiyor & Bilinmiyor \\
\hline Bingol-Kologlu $\mathrm{M}^{14}$ & 2007 & 13 & 1ay- 8 yaş & $\begin{array}{c}\% 46 \\
\text { Erkek-\%54 } \\
\text { Kız }\end{array}$ \\
\hline
\end{tabular}

\section{Epidemiyoloji}

NF nadir görülen bir hastalıktır. Erişkinlerde görülme sıklığı \%0.004 ile \%0.04 arasında değişmektedir. ${ }^{15,16}$ Erişkinlere göre çocuklarda daha az sıklıkta saptanmaktadır. Çocukluk çağında prevalansının milyon hasta başına 0.82.9 olduğu tahmin edilmektedir. ${ }^{17,18}$ Diğer yandan NF, hospitalize edilen erişkinlerin $\% 0.03$ 'ünü ve çocuklarında $\% 0.018$ 'ini oluşturmaktadır. ${ }^{19,20} \mathrm{Bu}$ kadar az görülmesi, hastalığa özgü bir bulgunun olmaması ve hızlı seyir göstermesi gibi etkenler hastalığın mortalitesinin yükselmesine neden olmaktadir. ${ }^{1}$

Literatürde hastalığın cinsiyet ayırımı göstermediği ifade edilmiştir. ${ }^{21}$ Ülkemizden yapılan yayınlarda da olguların \%56’sını kız ve \%44'ünü erkekler oluşturmuştur (Tablo 1). Hastalık yılın her döneminde görülmekle beraber özellikle Ocak-Nisan arasındaki soğuk aylarda sıklığının arttığı ifade edilmiştir. ${ }^{22}$ Bunun nedeni bu dönemlerde sıklığı artan virüs kaynaklı enfeksiyon hastalıkları olabilir. Hastalığın sıklığı yaşa göre değişmektedir, adölesan ve çocukluk yaş grupları dikkate alındığında özellikle 5 yaş altı çocuklarda daha sık görülür, bunların içinde özellikle yenidoğan dö- 
nemi ve 1-2 yaş arası sıklığın en fazla arttığı dönemler olarak kabul edilmektedir. ${ }^{23}$ Ülkemizden yapılan yayınlarda olguların \%46'sı 2 yaşın altında ve \%77'si de 5 yaşın altında idi (Tablo 1).

\section{Patoloji}

NF, subkutan doku ve fasya nekrozu ile kendini gösteren bir yumuşak doku enfeksiyonudur. Bakterilerin subkutan dokuyu invaze etmesi, endotoksin ve ekzotoksin salgılayarak doku iskemisi, likenifikasyon nekrozu ve sistemik hastalığa neden olması hastalığın temelini oluşturmaktadır. ${ }^{24}$ Fasya ödemli ve donuk gri renktedir, subepidermal nekrotik büller, subkutan yağ nekrozu ve yoğun bir nötrofil hakimiyeti gösteren inflamatuar cevap tipiktir, geç evrede ise intravasküler koagülasyon ve hemoraji saptanır. ${ }^{25}$

NF, 2 gruba ayrılır. Tip 1, en azından bir tane anaerob etkenin eşlik ettiği gram (+) veya gram (-)’lerin dahil olduğu multiple organizmalarla oluşturulan tablodur, sıklıkla göğüs, karın duvarı, kasık ve perianal bölgede görülür. ${ }^{26,27}$ Tip 2 ise, grup A streptokoklar (Streptokokus pyogenes), diğer tip streptokoklar veya stafilokoklar gibi tek tip mikroorganizma tarafından oluşturulan tablodur. Bu tip hastalar sıklıkla önceden sağlıklıdır, sıklıkla minör bir travmaya sekonder olarak başlamaktadır, lezyonlar sıklıkla baş, boyun ve ekstremitelerde saptanmaktadır. ${ }^{21}$ Son yıllarda methisilin-rezistan Stafilokokus aureus olguları daha fazla saptanmaya başlamıştır. ${ }^{28}$ Erişkin NF vakalarının çoğunu tip 1 oluşturmaktadır, buna rağmen mortalite açısından iki grup arasında herhangi bir farklılık saptanmamıştır. ${ }^{26,29,30}$ Ülkemizden yapılan yayınlarda \%44.8 olguda tip 1 ve \%55.1 olguda ise tip 2 NF saptanmıştır (Tablo 2), olguların \%81.7'sinde gram (+) ve \%18.1'inde de gram (-) etken patojen olarak kültürlerde üretilmiştir (Tablo 3).

\section{Risk faktörleri}

NF, sağlıklı bir bireyde görülüyorsa primer/idiopatik, bilinen bir hastalığa bağlı meydana geliyorsa sekonder olarak adlandırılır. Erişkinlerde hastalık çoğunlukla diabetes mellitus, obezite, kardiyo-vasküler bozukluklar ve immun supresyon gibi tabloları olanlarda gelişmektedir. ${ }^{31}$ Erişkinlerin aksine NF gelişen çocukların çoğu öncesinde sağlıklı olan bireylerdir. ${ }^{32}$ Çocukların \%50-80'inde hastalığı başlatan minör bir lezyon saptanabilmektedir. ${ }^{24,31,33}$ Çocuklarda bu lezyonlar sünnet, umbilikal ven kateterizasyonu, inguinal herni operasyonu, suçiçeği superenfeksiyonu, omfalit, ekstremite lezyonu, perineal enfeksiyon, baş-boyun lezyonları veya insekt bite olabilmektedir. ${ }^{34-38}$ Nonsteroid anti inflamatuvar ilaç (NSAİD)'lerin de kemotaksis, fagositoz ve bakterisidal aktivite gibi granülosit fonksiyonları bozarak bu tabloya neden olabildikleri kabul edilmektedir. ${ }^{39} \mathrm{NF}$ için en sık tespit edilen predispozan faktörler $\% 33$ olguda travma, \%25 olguda suçiçeği ve \%25 olguda sistemik hastalıktır. ${ }^{40}$ Ülkemizden yapılan yayınlarda olguların \%42.8'inde suçiçeği, \%19'unda travma, \%9.5'inde anal operasyona sekonder, \%9.5'inde NSAİD veya steroid gibi ilaçlar, \%9.5'inde perianal enfeksiyon, \%4.7'sinde omfalit ve \%4.7'sinde de dental abse başlatıcı etken olarak saptanmıştır (Tablo 2).

\section{Klinik bulgular}

Yumuşak doku enfeksiyonları; basitçe antibiyotik tedavisine yanıt alınabilen sellülit ve antibiyotik tedavisine rağmen geniş bir alanda progresif doku yıkımı ile seyreden NF gibi tablolardan oluşur. ${ }^{41}$ Erken aşamada NF kendini eritem, hassasiyet, 1sı artışı ve myalji gibi nonspesifik bulgularla gösterir, ${ }^{18,23,42}$ ülkemizden yapılan yayınlarda da olguların \%92'sinde benzer semptomlar saptanmıştır (Tablo 2). NF'de ilk olarak subkutan doku ve fasyanın tutulduğu dikkate alındığında, derinin tutulumu tanı için gerekli olmayan geç bir bulgudur, buna rağmen görünümü nedeniyle NF olgularının \%59-100'ü yanlışlıkla selülit tanısı almakta, bu da tablonun morbidite ve mortalitesinin artmasina neden olmaktadır. ${ }^{24,40,42} \mathrm{Bu}$ nedenle bu iki tablonun birbirinden erkenden ayırt edilmesi gerekir. Selülitli olgulara göre bu hastaların daha toksik görünmeleri ve enfeksiyon alanı sınırlarının belirsiz olması ayırt edici önemli klinik bulgular olarak kabul edilmektedir. ${ }^{42,43}$ Lezyonla orantısız ağrı, NF’nin tipik klinik belirtisi olarak kabul edilmektedir. ${ }^{23}$ Ülkemizden yapılan yayınlarda da sadece \%15.3 
Sakarya Tip Dergisi 2019;9(2):190-198

BEKDAȘ, Pediatrist Gözüyle Çocukluk Çağı Nekrotizan Fasiite Bakıș: Bir Derleme

\begin{tabular}{|c|c|c|c|c|c|}
\hline Kaynak & Başlama yeri & Hastalık tipi & Başlatıcı faktör & İlk bulgu & Ateş $\left({ }^{\circ} \mathrm{C}\right)$ \\
\hline Şentürk $S^{3}$ & Batın & 1 & Suçiçeği & Hassas eritem & B \\
\hline Sütçü $M^{4}$ & Perianal & 1 & Anal operasyon & Ekimoz & B \\
\hline Paksu Ş & $\begin{array}{c}\text { Üst } \\
\text { ekstremite }\end{array}$ & 2 & $\mathrm{Y}$ & Ağrılı cilt şişliği & 38.4 \\
\hline Gundeslioglu $\mathrm{AO}^{6}$ & Gögüus duvarı & 1 & Suçiçeği+NSAİD & Vezikül & $39 / 39.8$ \\
\hline Saz EU ${ }^{9}$ & Perine & 1 & İM tedavi & Ciltte renk değişikliği & 38.2 \\
\hline Kurekci $\mathrm{AE}^{10}$ & $\begin{array}{c}\text { Üst } \\
\text { ekstremite }\end{array}$ & 2 & Suçiçeği & Vezikül & 39 \\
\hline Delibaş $A^{11}$ & $\begin{array}{c}\text { Alt } \\
\text { ekstremite }\end{array}$ & 2 & NS+steroid & Ciltte renk değişikliği & 38.8 \\
\hline Ozkan $\mathrm{H}^{12}$ & Perine & 1 & $\mathrm{Y}$ & Hassas eritem & B \\
\hline Tanir $G^{13}$ & Ekstremite & 2 & B & B & B \\
\hline $\begin{array}{l}\text { Bingol-Kologlu } \\
\mathrm{M}^{14}\end{array}$ & $\begin{array}{l}\text { Batın, gluteal, boyun, } \\
\text { ekstremite }\end{array}$ & $\begin{array}{l}\% 39 \text { tip1, } \% 61 \\
\text { tip2 }\end{array}$ & $\begin{array}{l}\text { Suçiçeği, İM tedavi, } \\
\text { Omfalit }\end{array}$ & Ciltte renk değişikliği, selülit & $\% 92(+)$ \\
\hline
\end{tabular}

\begin{tabular}{|c|c|c|c|c|c|}
\hline Kaynak & WBC (X1000) & CRP & $\begin{array}{l}\text { Serum } \\
\text { sodyum }\end{array}$ & Radyolojik tanı & Yara kültürü \\
\hline Şentürk S ${ }^{3}$ & B & B & B & B & GABHS \\
\hline Sütçü $M^{4}$ & $4.1 / 3.2$ & $66 / 419$ & B & BT/USG & Üreme olmadı \\
\hline Paksu $\oint^{5}$ & 5.8 & 192 & B & $\mathrm{X}$-ray & Streptokokus pyogenes \\
\hline Gundeslioglu $\mathrm{AO}^{6}$ & $14.8 / 22.2$ & $83 / 72$ & $129 / 128$ & USG/BT & Üreme olmadi \\
\hline Akın $Y^{7}$ & 3.6 & 148 & B & USG & MRSA \\
\hline Kuzdan $C^{8}$ & B & B & B & MRI & Streptokokus pyogenes \\
\hline $\mathrm{Saz}_{\mathrm{EU}}{ }^{9}$ & 8.3 & 27 & B & $\mathrm{Y}$ & Psödomonas \\
\hline Kurekci $\mathrm{AE}^{10}$ & 19 & 24 & B & $\mathrm{Y}$ & GABHS \\
\hline Delibaş A ${ }^{11}$ & 10.8 & 172 & 133 & $\mathrm{Y}$ & Psödomonas \\
\hline Ozkan $\mathrm{H}^{12}$ & 11.8 & B & B & $\mathrm{Y}$ & Klebsiella pneumonia \\
\hline Tanir $G^{13}$ & B & B & B & B & GABHS \\
\hline $\begin{array}{l}\text { Bingol-Kologlu } \\
\mathrm{M}^{14}\end{array}$ & B & B & B & B & $\begin{array}{c}\text { Streptokokus pyogenes, MRSA, } \\
\text { Psödomonas }\end{array}$ \\
\hline
\end{tabular}

(NF: Nekrotizan Fasiit, Y:Yok, B:Bilinmiyor, WBC:Kan lökosit sayısı, CRP:C-reaktif protein, X-ray:Direkt grafi, USG:Ultrasonografi, BT:Bilgisayarlı tomografi, MRI:Megnetik rezonans görüntüleme, GABHS:Grup A $\beta$-hemolitik streptokok, MRSA: Metisilin rezistan Staphylococcus Aureus)

olguda selülit tablosuyla orantısız şiddetli ağrı varlığı saptanmıştır. Tablo ilerledikçe yüzeysel sinirleri besleyen damarlardaki mikrotrombüslerın gelişmesiyle ağrı ortadan kalkmaktadır. ${ }^{24,44}$ Lezyonların ilerlemesi çok hızlıdır, bu hız $2.5 \mathrm{~cm} /$ saate kadar çıkabilmektedir. ${ }^{32} \mathrm{Bu}$ progresyon, olguların hızla septik şoka girmesine sebep olmaktadır, bu gidişi durdurabilecek en önemli şey erken tanı konulma- sıdır. ${ }^{37}$ Başlangıçtan 3-4 gün sonra ise hemorajik büller, ciltte nekroz, mor cilt rengi, hipoestezi, duyusal veya motor defisit belirmektedir. ${ }^{24}$ NF'yi kuvvetle düşündürten bu bulgular vakaların ancak \%16'sında saptanabilmektedir. ${ }^{45}$ Literatürde saptanabilecek diğer bulgular sırasıyla kusma, karın ağrısı, öksürük ve ishaldir. ${ }^{18}$ 
Lezyonlar vücudun herhangi bir yerinde başlayabilir ancak bazı bölgelerde bu risk daha yüksektir. ${ }^{46}$ Yapılan çalışmalarda primer lezyon \%33-44 olguda alt ekstremitede, \%33 olguda perinede, \%22-25 olguda baş-boyunda, \%8-19 olguda üst ekstremitede, $\% 8$ olguda gögüste ve $\% 8$ olguda abdominal bölgede saptanmıştır. ${ }^{18,40}$ Ülkemizden yapılan yayınlarda primer lezyon \%31 olguda alt ekstremitede, \%20.6 olguda abdominal bölgede, \%17.2 olguda üst eksremitede, $\% 10.3$ olguda perinede, $\% 6.8$ olguda perianal bölgede, \%6.8 olguda gögüüste ve \%6.8 olguda da baş-boyun bölgesinde saptanmıştır (Tablo 2).

$\mathrm{Bu}$ hastaların fizik muayenesinde olguların \%97,2'sinde eritem ve $\% 97,1$ 'inde lokalize ağrı saptanmaktadır, ${ }^{18}$ ülkemizden yapılan yayınlarda da olguların \%90'ında benzer fizik muayene bulguları saptanmaktadır (Tablo 2). Bu hastalarda saptanabilen krepitasyon NF'ye daha spesifik bir bulgudur ve bakteriler tarafindan gaz üretildiğine işaret etmektedir, ancak bu bulgu her vakada saptanamamaktadir. $^{37}$

\section{Tanı}

NF’yi gösterecek spesifik bir laboratuvar bulgusu yoktur, ancak yapılan çalışmalarda bu hastaların bazı biyokimyasal parametrelerinde değişiklikler olduğu saptanmıştır, hemoglobin $(\mathrm{Hgb})$ ve serum sodyum $(\mathrm{Na})$ düşüklüğü, C-reaktif protein (CRP) ve kan lökosit sayısı (WBC) yüksekliğinin hastada muhtemel bir NF riskinin varlığına işaret sayılmıştır. NF tanısı konulanlardan \%83 olguda $\mathrm{Hgb}<12,5 \mathrm{~g} / \mathrm{dl}, \% 80$ olguda $\mathrm{CRP}>150 \mathrm{mg} / \mathrm{dl}, \% 50$ olguda $\mathrm{Na}<135 \mathrm{mEq} / \mathrm{l}$ ve $\% 25$ olguda $\mathrm{WBC}>15 \times 103 / \mu \mathrm{l}$ bulunmuştur. ${ }^{40}$ Ülkemizden yapılan yayınlarda ise \%33.3 olguda $\mathrm{CRP}>150 \mathrm{mg} / \mathrm{dl}, \% 100$ olguda $\mathrm{Na}<135 \mathrm{mEq} / \mathrm{l}, \% 20$ olguda WBC $>15 \times 103 / \mu$ l bulunmuştur (Tablo 3).

WBC, CRP, Hgb, Na, kreatinin ve glukoz gibi altı bağımsız laboratuvar parametresinden oluşan "NF için Laboratuvar Risk Göstergesi” (LRINEC) skorunun 6 veya üzerinde olmasının erişkin hastalarda pozitif prediktif değerinin \%92 olduğu, bu nedenle NF tanısında kullanılabileceği belirtil- miştir. ${ }^{47}$ Ancak Kumar ve ark çalışmasında bu skor sisteminin sadece \%50 olguda hastalığı öngörmesinden dolayı çocuk hastalarda kullanılmaması önerilmiştir. ${ }^{17}$ Pediatrik NF için daha uygulanabilir bir yaklaşım olarak öykü ve fizik muayeneye ek olarak öncelikle serum CRP'nin değerlendirilmesi, CRP değerinin $>20 \mathrm{mg} / \mathrm{dl}$ olduğu vakalarda serum $\mathrm{Na}$ değerine bakılması önerilmektedir, CRP $>20$ $\mathrm{mg} / \mathrm{dl}$ ve serum $\mathrm{Na}<135 \mathrm{mEq} / \mathrm{l}$ olmasının pediatrik NF'yi öngörmede oldukça etkili olduğu ve klinisyenin bu bulguları muhtemel acil bir operasyon için dikkate alması gerektiği ifade edilmiştir. ${ }^{48}$ Ülkemizden yapılan yayınlarda olguların tümünde $\mathrm{CRP}>20 \mathrm{mg} / \mathrm{dl}$ ve $\mathrm{Na}<135 \mathrm{mEq} / \mathrm{l}$ saptanmış olması nedeniyle, bu değerlendirme metodu pediatrik NF'yi öngörmede daha etkili kabul edilmiştir. Bunlara ek olarak \%8,3 vakada transaminaz yüksekliği, $\% 11,1$ vakada tübülopati ve $\% 27,7$ vakada koagülopati de saptanabilmektedir. ${ }^{18}$

Yapılan yara kültürlerinde olguların $\% 75$ inde $\beta$-hemolitik streptokoklar, \%33'ünde stafilokoklar üretilmiştir. ${ }^{40}$ Kumar ve ark çalışmasında bu oranlar \%50 ve \%50 idi. ${ }^{17}$ $\mathrm{Bu}$ hastalarda en sık üretilen üçüncü etken ise psödomonaslardır, Acinetobacter baumani \%8 olguda saptanırken, $\% 17$ olguda ise etken üretilememektedir. ${ }^{23,40}$ Ülkemizden yapılan yayınlarda olguların \%68.1'inde streptokoklar, \%13.6'sında stafilokoklar, \%13.6'sında psödomonaslar ve $\% 4.5$ 'inde klebsiella etken patojen olarak kültürlerde üretilmiştir (Tablo 3).

NF tanısında direkt grafi, ultrasonografi (USG), bilgisayarlı tomografi (BT) ve manyetik rezonans görüntüleme (MRI) gibi radyolojik değerlendirmelerde kullanılmıştır. ${ }^{49}$ Direkt grafide subkutan alanda hava görünümü saptanabilmektedir. ${ }^{17}$ USG'de, kalınlaşmış fasyal tabakalar, sıvı lokülasyonları ve subkutan doku ödemi saptanabilmektedir. ${ }^{49}$ Direkt grafi veya BT'de cilt altı dokuda gaz varlığının saptanması NF için tanısal bir bulgudur, ancak bu bulgu olguların ancak \%17-29'unda saptanabilmektedir. ${ }^{24,30,50}$ BT ile de subkutan gaz veya abse oluşumu görülebilir. Ancak NF düşünülen hastalarda radyolojik görüntülemeler be- 
lirgin patoloji göstermese bile, klinik bulgulara dayanarak da cerrahi girişim uygulanabilir. ${ }^{51}$ T2 ağırlıklı MRI kesitleri, NF tanısında yüksek duyarlılığa sahiptir, MRI ile NF nonnekrotizan yumuşak doku enfeksiyonundan ayırtedebilir. $^{52}$ Ülkemizden yapılan yayınlarda NF tanısı için \%9 olguda X-ray, \%27.2 olguda USG, \%18.1 olguda BT ve \%9 olguda da MRI kullanılmıştır (Tablo 3).

Nadiren görülmesi hastalığın tanısı için en önemli dezavantajdır. Daha önceden sağlıklı olan bir bireyde antibiyoterapiye rağmen hızla ilerleyen selülit tablolarında NF akla getirilmelidir, özellikle lezyonla orantısız ağrı dikkat çekmelidir. Bu tarz vakalarda $\mathrm{CRP}>20 \mathrm{mg} / \mathrm{dl}$ ve $\mathrm{Na}<135$ $\mathrm{mEq} / \mathrm{l}$ saptanması pediatrik NF'yi öngörmede oldukça etkilidir. ${ }^{48}$ USG'de, kalınlaşmış fasyal tabakalar, subkutan doku ödemi veya BT'de cilt altı dokuda gaz varlığı NF için tanısal bulgulardır. ${ }^{49}$ Tanı konulduktan sonra hızlıca tedaviye başlanmalıdır. ${ }^{53}$

\section{Tedavi}

NF’nin tedavisi hizlıca ve beraberce uygulanan sıv1-elektrolit dengesinin düzenlenmesi, geniş spektrumlu antibiyotik tedavisi ve erken debridmandır, ${ }^{51}$ bu yaklaşımlardaki gecikme morbidite ve mortaliteyi belirgin olarak arttırmaktadır. ${ }^{16,54}$ Ülkemizden yapılan yayınlarda olguların \%37.9'unda IVV antibiyotik tedavisinin verildiği saptanmıştır (Tablo 4). Başlatılan antibiyotik tedavisi, beklenen patojenlere yönelik olmalı, debridmanlar devam ettiği sürece verilmeli, klinik düzelme görülmeden ve ateş düşmeden de kesilmemelidir. ${ }^{55} \mathrm{Bu}$ hastalara $\beta$ laktam+klindamisin veya $\beta$ laktam+vankomisin kombinasyonu kullanılması önerilmektedir. ${ }^{17,18}$ Ülkemizden yapılan yayınlarda da $\beta$ laktam+vankomisin, $\beta$ laktam+klindamisin/gentamisin veya $\beta$ laktam+metronidazol kombinasyonlarının tedavide kullanıldığı görülmüştür (Tablo 4). Antibiyotik tedavi süresinin 14 gün olması önerilmektedir. ${ }^{24,30,50}$

NF'de intravenöz immunglobulin (İVİG) kullanımı erişkinler gibi çocuklarda da önerilmektedir. ${ }^{17,56,57}$ Erişkinlerde yapılan bir çalışmada antibiyotik+yüksek doz IVİG tedavisi uygulananlarda cerrahi girişimin ya hiç gerekmediği veya minimal kullanıldı̆̆ı gösterilmiştir, ancak çocuklarda cerrahi girişim uygulanmadan sadece İVİG kullanılması konusunda bir fikir birliği yoktur, kullanılacaksa da sadece yardımcı tedavi olarak kullanılması önerilmektedir. ${ }^{17,56}$ Ülkemizden yapılan yayınlarda \%64 olguda IVİG’in yardımcı

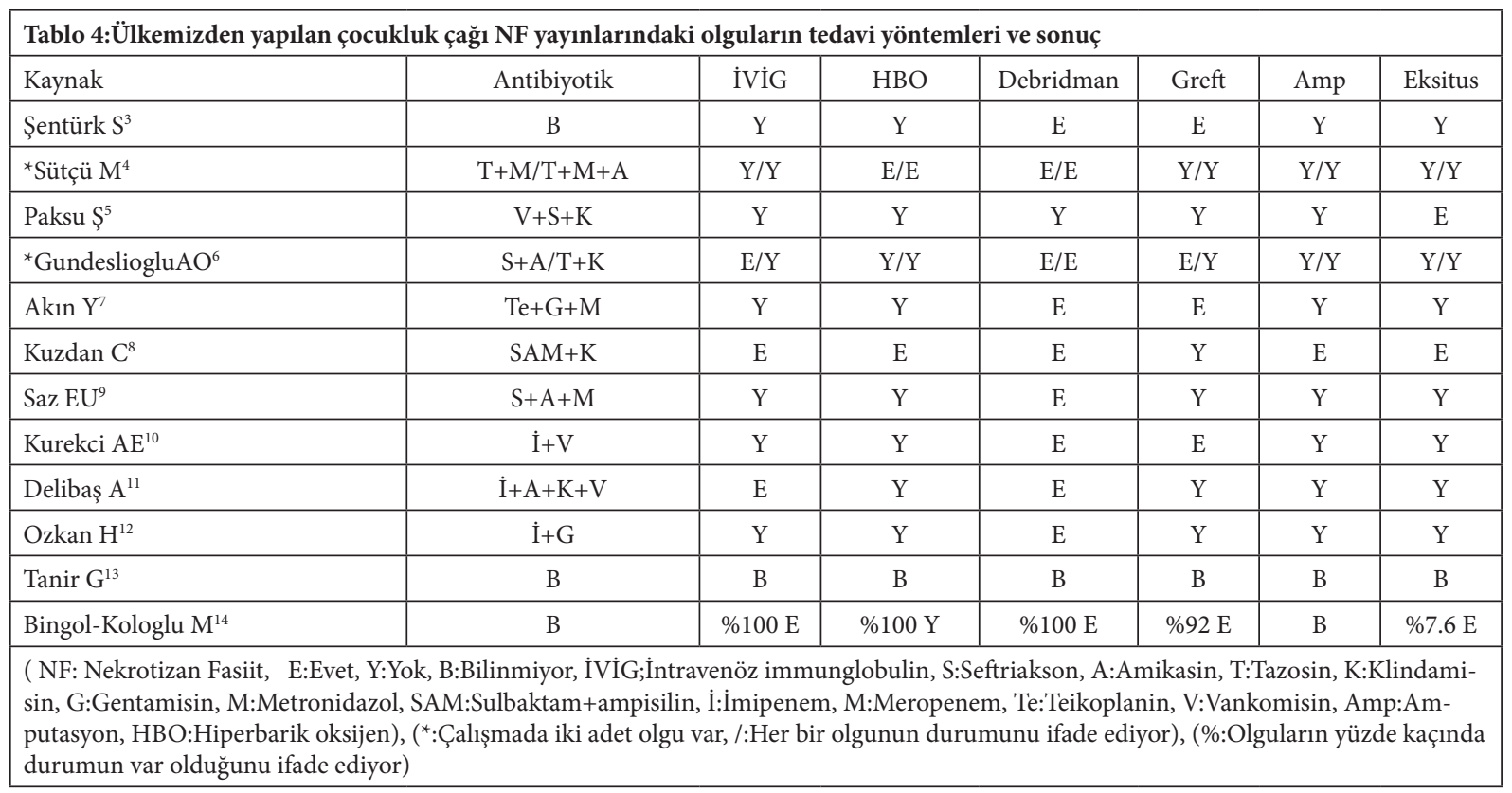


tedavi yöntemi olarak kullanıldı̆̆ı saptanmıştır (Tablo 4). Bir diğer öneri ise hiperbarik oksijen tedavisidir. Bu tedavi, doku iyileşmesini hızlandırabilmesi ve antimikrobiyal aktiviteyi arttırabilmesi nedeniyle önerilmektedir. ${ }^{58}$ Özellikle de gaz oluşumunun görüldüğü vakalarda kullanılmas1 önerilmektedir. ${ }^{51}$ Ülkemizden yapılan yayınlarda $\% 12$ olguda hiperbarik oksijen tedavisinin kullanıldığı saptanmiştır (Tablo 4).

Cerrahi tedavi hayat kurtarıcıdır. Cerrahi tedavide, geniş fasyatomi insizyonu ve fasyal planların eksplorasyonu ile tüm nekrotik dokuların drenajı ve eksizyonu yapılmaktadir. ${ }^{51}$ Cerrahi tedavinin erken uygulanması çok önemlidir, bu tedavinin 24 saatten fazla geciktirilmesi mortaliteyi 9 kat arttırmaktadır. ${ }^{24}$ Tek bir girişim genellikle yeterli olmamakta, hastaların çoğunda 24-36 saatlik aralıklarla çoklu debridman ihtiyacı olmaktadır. ${ }^{17,18}$ Ülkemizden yapılan yayınlarda olguların tümüne debridman tedavisinin uygulandığı saptanmıştır (Tablo 4). Dokunun aşırı ödemli olması nedeniyle yaraların açık bırakılması çok önemlidir. Olguların \%27'sine cilt grefti ve \%25'ine flep ihtiyacı da olabilmektedir. ${ }^{18,40}$ Ülkemizden yapılan yayınlarda olguların \%68'inin cilt grefti veya flep ihtiyacı gösterdiği saptanmıştır (Tablo 4). Rekonstrüktif cerrahi hastaların genel durumu düzeldikten ve enfeksiyon eradike edildikten sonra yapılmalıdır. Ampütasyon ise ekstremite tutulumunda hayat kurtarıcı bir girişim olarak kabul edilmektedir. ${ }^{21}$ Gövde ve perine tutulumunda amputasyon yapılamayacağ 1 için mortalite daha yüksek olabilmektedir. ${ }^{46}$ Yapılan yayınlarda olguların \%2.7'sine amputasyon uygulandığı görülmüştür. ${ }^{18}$ Ülkemizden yapılan yayınlarda ise daha fazla olguya (\%8.3) amputasyon yapıldığı görülmüştür (Tablo 4).

Erişkin döneme göre, hastalığın çocukluk çağında saptanma sıklığı gibi mortalitesi de düşüktür. Kronik hastalıkların daha sık görüldüğü erişkin çağdaki NF’nin mortalitesi \%18-49 arasında değişmektedir. ${ }^{58,59}$ Mortaliteyi etkileyen en önemli faktörler cerrahi girişimin yapılıp yapılmaması ve yapıldıysa zamanıdır, cerrahi girişim yapılanlarda mortalite \%30-50 arası iken, yapılmayanlarda \%80-100’lere kadar çıkabilmektedir, tanı ile tedavi arasındaki sürenin 90 saat üstü olduğu vakalar sıklıkla kaybedilirken, 25 saat altında olanların hayatta kaldığı tespit edilmiştir. ${ }^{50,60}$ Hastalığın çocukluk çağındaki mortalitesi ise \%5-17.9 arasında değişmektedir. ${ }^{18,20,23,61,62}$ Ülkemizden yapılan yayınlarda NF olgularının \%8'i ölüm ile sonlanmıştır (Tablo 4). En büyük seri olan Bingol-Kologlu ve ark.'nın çalışmasında mortalite oranı \%7,6 olarak tespit edilmiştir. ${ }^{14}$ Mortaliteyi arttıran en önemli nedenler tanıdaki ve uygun tedavinin başlanmasındaki gecikme olarak kabul edilmektedir. ${ }^{63}$

NF'de en sık görülen komplikasyon \%33 olguda septik şoktur, diğer komplikasyonlar ise kompartman sendromu, akut respiratuvar distres sendromu, testis atrofisi, tromboz ve septik artrittir. ${ }^{40}$ Hastalığın seyrini belirleyen temel faktörler, etken patojenin virülansı, olgunun yaşı, enfeksiyonun genişliği, ilk debridmanın uygulanma zamanı, eşlik eden sistemik hastalıklar ve malnütrisyondur. ${ }^{32} \mathrm{Bu}$ özelliklere bağlı olarak mortalite artmaktadır. Bu olgularda ölüm sepsis, dissemine intravasküler koagülopati veya çoklu organ yetmezliği gibi nedenlerin birine bağlıdır. ${ }^{64}$ Ülkemizden yapılan yayınlarda ise ölümcül seyreden vakaların tümünde septik şok tablosu bulunmaktaydı.

Sonuç olarak hızlı ilerleyen bir tablo olması nedeniyle erken tanı hayat kurtarıcıdır. Ancak hastalığın nadir olması ve hastalığa özgü patognomonik bulgunun olmaması tanının gecikmesine neden olmaktadır. Ayrıca klinik olarak eritemle seyreden diğer yumuşak doku enfeksiyonları ile de kolayca karışabilmektedir. Uygun tanıyı koymanın en önemli yolu uygun hastalarda hekimin NF tanı eşiğini düşük tutmasıdır. En önemli tedavi yaklaşımı erken debridmandır. Tanı ve tedavideki gecikmeye bağlı olarak hastalar sıklıkla septik şok tablosu nedeniyle kaybedilmektedir. 


\section{Sakarya Tip Dergisi 2019;9(2):190-198}

BEKDAȘ, Pediatrist Gözüyle Çocukluk Çağı Nekrotizan Fasiite Bakıș: Bir Derleme

\section{Kaynaklar}

1. Bayer ML, Drolet BA. Disorders of the Mucous Membranes, In: Kliegman RM, Stanton BF, St Gemell JW, Schor NF. eds. Nelson Textbook of Pediatrics 20th ed. Philadelphia, PA: Elsevier Saunders 2016;3205-6

2. Wilson B. Necrotizing fasciitis. Am Surg 1952;18:416-31

3. Șentürk S, Tosun Z, Özkan A, Karaçor Z, Savacı N. Ciddi bir suçiçeği komplikasyonu: Nekrotizan Fasiit:Olgu sunumu. Türk Plast Rekonstr Est Cer Derg 2002;10(3):216-17

4. Sütçü $M$, Şık GD, Gün F, Somer A, Salma N. Fournier's gangrene after anorectal surgery in infant: Two case reports. TJTES 2016;22(5):505-508

5. Paksu Ș, Kalaycı AG, Okur EG, Öztürk F. Nekrotizan Fasiit:Nadir bir olgu. OMU Tip Dergisi 2006;23(3): 101-105

6. Gundeslioglu AO, Selimoglu MN, Toy H. Is it necrotizing fasciitis or necrotizing cellulitis after varicella zoster infection? Two case reports. Ann Plast Surg 2014;73(2):202-4

7. Akın Y, Celayir AC, Aköz T, Civan HA, Kurt G, Ağzıkuru T, Sahin C. Necrotizing fasciitis of the perineum. World J Pediatr 2013;9(2):185-7

8. Kuzdan C, Soysal A, Altinkanat G, Aksu B, Söyletir G, Bakir M. Recurrent fatal necrotizing fasciitis due to Streptococcus pyogenes in a child with hereditary sensory and automic neuropathy type IV. Jpn J Infect Dis 2011;64(2):147-9

9. SazEU, Anik A, Tanriverdi HI, Anik A, Ergün O. Pseudomonas necrotizing fasciitis following an intramuscular injection in an immunocompetent child. Pediatr Int 2010;52(2):e114-6

10. Kurekci AE, Aydin HI, Atay AA, Akar N, Cetan T, Ozcan O, Gokcay E. Familial high factor VIII level in a child with necrotizing fasciitis complicating primary varicella infection. Pediatr Hematol Oncol 2005;22(3):219-22

11. Delibaș A, Bek K, Bülbül M, Demircin G, Baysun S, Oner A.Necrotizing fasciitis in a child: a rare complication of idiopathic nephrotic syndrome. Pediatr Nephrol 2005;20(1):99-101

12. Ozkan H, Kumtepe S, Turan A, Funda, Corapçioglu, Ozkan S.Perianal necrotizing fasciitis in a neonate. Indian J Pediatr 1997;64(1):116-8

13. Tanir G, Tonbul A, Tuygun N, Aydemir C, Ertan U. Soft tissue infections in children: a retrospective analysis of 242 hospitalized patients. Jpn J Infect Dis 2006;59(4):258-60

14. Bingol-Kologlu M, Yildiz RV, Alper B, Yagmurlu A, Ciftci E, Gökçora IH, et al. Necrotizing fasciitis in children: diagnostic and therapeutic aspects. J Pediatr Surg. 2007;42:1892-1897

15. Ellis Simonsen SM, van Orman ER, Hatch BE, Jones SS, Gren LH, Hegmann KT, Lyon JL. Cellulitis incidence in a defined population. Epidemiol Infect 2006;134(2):293-9

16. Endorf FW, Klein MB, Mack CD, Jurkovich GJ, Rivara FP. Necrotizing soft-tissue infections: differences in patients treated at burn centers and non-burn centers. J Burn Care Res 2008;29(6):933-8

17. Kumar M, Meeks A, Kearl L. Necrotizing Fasciitis of the Chest Wall: Report of Pediatric Cases. Pediatr Emer Care 2015;31: 656-660

18. Eneli I, Davies HD. Epidemiology and outcome of necrotizing fasciitis in children: an active surveillance study of the Canadian Paediatric Surveillance Program. J Pediatr. 2007;151:7984

19. Fujisawa N, Yamada H, Kohda H, Tadano J, Hayashi S. Necrotizing fasciitis caused by Vibrio vulnificus differs from that caused by streptococcal infection. I Infect 1998 May;36(3):313-6

20. Fustes-Morales A, Gutierrez-Castrellon P, Duran-McKinster C, Orozco-Covarrubias L, Tamayo-Sanchez L, Ruiz-Maldonado R. Necrotizing fasciitis: report of 39 pediatric cases. Arch Dermatol. 2002;138:893-899

21. Lancerotto L, Tocco I, Salmaso R, Vindigni V, Bassetto F. Necrotizing fasciitis: Classification, diagnosis, and management. J Trauma 2012;72: 560-566

22. Luca-Harari B, Ekelund K, van der Linden M, Staum-Kaltoft M, Hammerum AM, Jasir A. Clinical and epidemiological aspects of invasive Streptococcus pyogenes infections in Denmark during 2003 and 2004. J Clin Microbiol. 2008;46:79-86

23. Zundel S, Lemaréchal A, Kaiser P, Szavay P. Diagnosis and treatment of pediatric necrotizing fasciitis: a systematic review of the literature. Eur J Pediatr Surg 2017;27(2):127-137

24. Wong CH, Chang HC, Pasupathy S, Khin LW, Tan JL, Low CO. Necrotizing Fasciitis: Clinical presentation, Microbiology, and Determinants of Mortality. J Bone Joint Surg Am 2003; 85-A(8): 1454-60

25. Aronoff DM, Bloch KC. Assessing the Relationship Between the Use of Nonsteroidal Antiinflammatory Drugs and Necrotizing Fasciitis Caused by Group A Streptococcus. Medicine 2003;82(4):225-235

26. Andreasen TJ, Green SD, Childers BJ. Massive infectious soft-tissue injury: diagnosis and management of necrotizing fasciitis and purpura fulminans. Plast Reconstr Surg. 2001;107:1025-1035

27. Low DE, McGeer A. Skin and soft tissue infection: necrotizing fasciitis. Curr Opin Infect Dis. 1998;11:119-123
28. Purcell K, Fergie JE. Exponential increase in community-acquired methicillin-resistant Staphylococcus aureus infections in South Texas children. Pediatr Infect Dis J 2002;21(10):988989

29. Edlich RF, Cross CL, Dahlstrom JJ, Long WB III. Modern concepts of the diagnosis and treatment of necrotizing fasciitis. J Emerg Med 2010;39(2):261-265

30. Green RJ, Dafoe DC, Raffin TA. Necrotizing fasciitis. Chest. 1996;110:219-229

31. Vayvada H, Demirdover C, Menderes A, Karaca C. Necrotising fasciitis in the central part of the body: diagnosis, management and review of the literature. Int Wound J 2013;10(4):46672

32. Abbott RE, Marcus JR, Few JW, Farkas AM, Jona J. Necrotizing fasciitis in infancy: an uncommon setting and a prognostic disadvantage. J Pediatr Surg 1999;34(9):1432-4

33. Sarani B, Strong M, Pascual J, Schwab CW. Necrotizing fasciitis: current concepts and review of the literature. J Am Coll Surg 2009;208:279-88

34. Ward L, Eisenson D, Fils JL. Fournier's gangrene of the penis in a 12-year-old patient secondary to phimosis. R I Med J (2013);2016;99(12):45-46

35. Goldberg GN, Hansen RC, Lynch PJ. Necrotizing fasciitis in infancy: report of three cases and review of the literature. Pediatr Dermatol 1984;2(1):55-63

36. Moss RL, Musemeche CA, Kosloske AM. Necrotizing fasciitis in children: prompt recognition and aggressive therapy improve survival. J Pediatr Surg 1996;31(8):1142-6

37. Pfeifle VA, Gros SJ, Holland-Cunz S, Kampfen A. Necrotizing fasciitis in children due to minor lesions. J Ped Surg Case Reports 2017;(25):52-55

38. Shirley R, Mackey S, Meagher P. Necrotising fasciitis: a sequelae of varicella zoster infection. J Plast Reconstr Aesthet Surg 2011;64(1):123-7

39. Brun-Buisson C, Saada M, Trunet P, Rapin M, Roujeau J, Revuz J. Haemolytic streptococcal gangrene and non-steroidal anti-inflammatory drugs. Br Med J Clin Res 1985;290:1786

40. VanderMeulen H, Pernica JM, Roy M, Kam AJ. A 10-Year Review of Necrotizing Fasciitis in the Pediatric Population: Delays to Diagnosis and Management. Clinical Pediatrics 2016;1-7

41. Singh G, Sinha SK, Adhikary S, Babu KS, Ray P, Khanna SK. Necrotizing infections of soft tissues-a clinical profile. Eur J Surg 2002; 168: 366-371

42. Wang YS, Wong CH, Tay YK. Staging of necrotizing fasciitis based on the evolving cutaneous features. Int J Dermatol. 2007;46:1036-1041

43. Hsieh T, Samson LM, Jabbour M, Osmond MH. Necrotizing fasciitis in children in eastern Ontario: a case-control study. CMAJ 2000;393-396

44. Hakkarainen TW. Necrotizing Soft Tissue Infections: Review and Current Concepts in Treatment, Systems of Care, and Outcomes. Curr Probl Surg. 2014; 51(8): 344-62

45. Callahan TE, Schecter WP, Horn JK. Necrotizing soft tissue infection masquerading as cutaneous abscess following illicit drug injection. Arch Surg 1998;133:812-817

46. Levine EG, Manders SM. Life-threatening necrotizing fasciitis. Clin Dermatol 2005;23:1447

47. Wong C, Khin L, Heng K, Tan KC, Low C. The LRINEC (Laboratory Risk Indicator for Necrotizing Fasciitis) score: a tool for distinguishing necrotizing fasciitis from other soft tissue infections. Crit Care Med 2004;32:1535-1541

48. Putnam LR, Richards MK, Sandvall BK, Hopper RA, Waldhausen JHT, Harting MT. Laboratory evaluation for pediatric patients with suspected necrotizing soft tissue infections: A case-control study. J Pediatr Surg 2016;51:1022-25

49. Donnelly L, Frush D, O'Hara SM, Bissett GS. Necrotizing myofasciitis: An atypical cause of "acute abdomen" in an immunocompromised child. Pediatr Radiol 1998; 28:109-111

50. McHenry CR, Piotrowski JJ, Petrinic D, Malangoni MA. Determinants of mortality for necrotizing soft-tissue infections. Ann Surg 1995;221:558-563

51. Scher RL. Hyperbaric oxygen therapy for necrotizing cervical infections. Adv Otorhinolaryngol 1998;54:50-8

52. Edlich RF, Cross CL, Dahlstrom JJ, Long WB III. Modern concepts of the diagnosis and treatment of necrotizing fasciitis. J Emerg Med 2010;89:7-36

53. Young MH, Aronoff DM, Engleberg NC. Necrotizing fasciitis: pathogenesis and treatment. Expert Rev Anti Infect Ther 2005;3(2):279-294

54. Legbo JN, Shehu BB. Necrotising fasciitis: experience with 32 children. Ann Trop Paediatr. 2005;25:183-189

55. Gündeş S, Türel Ö. Ciltaltı enfeksiyonları ve tedavisi. Ankem 2007;21(2):125-135

56. Norrby-Teglund A, Muller MP, McGeer A, Gan BS, Guru V, Bohnen J, et al. Successful management of severe group A streptococcal soft tissue infections using an aggressive medical regimen including intravenous polyspecific immunoglobulin together with a conservative surgical approach. Scand J Infect Dis 2005;37:166-72

57. Darenberg J, Ihendyane N, Sjolin J, Aufwerber E, Haidl S, Follin P, et al. Intravenous im 
Sakarya Tip Dergisi 2019;9(2):190-198

BEKDAȘ, Pediatrist Gözüyle Çocukluk Çağı Nekrotizan Fasiite Bakıș: Bir Derleme

\section{Kaynaklar}

munoglobulin $G$ therapy in streptococcal toxic shock syndrome: a European randomized, double-blind, placebo-controlled trial. Clin Infect Dis 2003;37:333-40

58. Leung AK, Eneli I, Davies HD. Necrotizing fasciitis in children. Pediatr Ann 2008;37:704-

59. Yilmazlar T, Ozturk E, Alsoy A, Ozguc H. Necrotizing soft tissue infections: APACHE II score, dissemination, and survival. World J Surg 2007;31(9):1858-62

60. Magala J, Makobore P, Makumbi T, Kaggwa S, Kalanzi E, Galukande M. The clinical presentation and early Outcomes of necrotizing fasciitis in a Ugandan Tertiary Hospitala prospective study. BMC Res Notes 2014; 7:476
61. Endorf FW, Garrison MM, Klein MB, Richardson A, Rivara FP. Characteristics, therapies, and outcome of children with necrotizing soft tissue infections. Pediatr Infect Dis J. 2012;31:221-223

62. Totapally BR. Epidemiology and Outcomes of Hospitalized Children With Necrotizing Soft-Tissue. Infections Pediatr Infect Dis J 2017;36:641-644

63. Cainzos M, Gonzalez-Rodriguez FJ. Necrotizing soft tissue infections. Curr Opin Crit Care. 2007;13(4):433-439

64. Nazir Z. Necrotizing fasciitis in neonates. Pediatr Surg Int 2005;21(8):641-644 